\title{
The Regional Health Sovereignty Performance at the External Border Islands in Republic of Indonesia
}

\author{
Hasim As'Ari \\ Official Human Resources Development AgencyOf Riau Islands Province \\ Istana Kota Piring Provinvial Government Centre Dompak Island \\ Tanjungpinang, Indonesia \\ Email: asari.hasim2014@gmail.com
}

\begin{abstract}
The purpose of this study is to distinguish the organizational structure performance of the Natuna District Health Office as a regional government organization that carries out the health sector authority in border areas or outermost islands in Indonesia. The research used descriptive method in a qualitative approach and involved 12 informants which were analyzed in depth so as to explain the exact performance of the organizational structure. The results of the study explain that as an area that faces pressure from problems that are different from other regions in Indonesia, Natuna regency always allocates the good financial resources. However, the organizational structure performance which describes the organization and also the management still requires serious attention and continuous improvement efforts.
\end{abstract}

Keywords: Organizational; structure; Performance; Outer-border Island.

Link DOI : http://dx.doi.org/10.31314/pjia.7.2.94-100.2018 


\section{INTRODUCTION}

The Implementation of Regional Autonomy in Indonesia based on Law No. 23 year of 2014 which Regional Government concerning emphasizes the importance of clean and clear governance for improving the quality of public services that make the citizen's welfare and equitable development would be demands for reform to the sustainable development goals in the globalization era. Hence, it is necessary to implement a good governance order, in which the realization of cooperation and responsibility between the local government and all stakeholders for carrying out their respective functions and roles. To achieve this, the bureaucratic employee in the region must be oriented to performance and improve the quality of public services by applying the excellent service model to the community, while the community should provide support in the form of participation and adherence to the system and service procedures applied.

Nowadays, the public services which carried out by the local government official still have a lot of weaknesses, hence they wouldn't meet the quality as expected by the community. This phenomenon is still visible with various public complaints conveyed through the mass media, so that it can cause a wretched image for the local government official which will reducing the public trust and influence the authority of government institutions in citizen's experiences, because the main function of the government is to serve the citizen then the government should continue to improve service quality comprehensively.

Although the facts in the past show the behavior of the official who prefer to be served rather than serve(Robinson, 2015) placing the top bureaucratic leaders on the highest pyramid while the citizens are in the lower position. This is very different from the ideal formation in the reinventing government model(Bruk, 2012)which puts the citizens at the top of the pyramid or better known as customer driven government. This is a challenge for the government, especially the regional government to prioritize the public services and governance effectiveness and efficiency, because it is not only related to technical problems but also the mentality.

The increasing of citizens demand for the quality of public services is apparently closely related to the moral issues and ethical bureaucratic ethics. The bureaucrats really need ethical sensitivity, so they can provide services to the community. This means, the implementation of public service duties, will only run well, if supported by morals and ethics, as well as the attitude and professional officialactions, in carrying out the task (Baartman \& De Bruijn, 2011). So that in turn it will be able to improve the effectiveness of public services, carried out by government officials. For this reason, it is necessary to emphasize the work ethic of the bureaucracy that is oriented towards professionalism, so that the performance and image of the bureaucracy will be better.

In particular, the portrait of the decentralization practice can be narrowed 
down to the implementation of the authority of the health sector in Natuna Regency. Based on data and information, the identification of the most important problems (Natuna District Health Office Strategic Plan, 2016-2021)is as follows.

1. The lack on institutional governance.

2. The community low access, especially the poor to health services, both physically and mentally.

3. Low levels of healthy and clean life behavior in the community.

4. Limited maternal and child health services are in line with health standards.

5. Still high pain caused by the direct infectious diseases, degenerative diseases and unhealthy environments.

6. Limited human resources, both in quantity, quality and distribution of health resources.

7. Limited availability and affordability of medicines and medical supplies.

8. The lack of Management System for Overcoming Extraordinary Events.

9. The capabilities and Health management Information Systems not optimal yet.

10. There is still a gap in health development between Natuna and other regions in Indonesia, which is due to the outermost regions in Indonesia and it is quiet necessary to prepare a better health order. More in-depth factual conditions that are shown through the results of dynamic structures application in the Natuna District Health Office also explains that there are still gaps that illustrate the lack of optimal performance of existing structures.
So that it takes a variety of concrete steps in the future, to provide the best uses and outcomes for the community, especially in achieving the level of citizens welfare in the field.

According to (Toyota, 2013)the preparation of the organizational structure must truly describe the organization as a whole. It can be said that the organizational structure is a visible or tangible picture of the organization. Thus the organizational structure is also linear with the strategies, challenges and problems faced by the organization specifically.

The appropriate organizational structure for good organizational performance will depend on the problem, citizen demand service and the challenges it faceslinearly. Based on the phenomenon and the literature discussion, this study intends to describe the organizational structure performance of the Natuna District Health Office in terms of the Perspective of Authority in the Health Sector in the Regions. This thought and motivation is also an effort to align the health service applications in Natuna as the outermost island region where bordering to other countries.

\section{RESEARCH METHODS}

This research was carried out in Natuna Regency. The research location selection is based on the consideration that the health sector development efforts in Natuna Regency, which have become the main concern of the Indonesian 
government in particular accelerating the achievement of physical health facilities and health official that aim to improve the quality and quality of the health of the people in border areas and outer islands.

This study uses a descriptive method, with an explanatory by approaching and collecting data at once at a time where each research subject is only measured once and measurements are taken on the same variables the research subject is observed at the same time for answer a problem in the current situation whose results are used for planning improvements. This descriptive research carried out through an inductive approach is a method of research methods that study and observe the problems of society by collecting data, facts that are real and pure from experience in the community to be analyzed and interpreted appropriately so as to cause business or painting about the problem and the relationship between multiple phenomena and the influence of the phenomenon. The use of this method is expected to be able to answer and solve existing problems after making a thorough and thorough understanding and deepening of the object under study and describing conclusions according to the conditions and time.

\section{RESULT AND DISCUSSION}

Human resources as the government officials are important factors of the benchmarks that always get a framework assessment of implementing the local autonomy. Based on the results of the study explained that the better quality of human resources involved in implementing authority in the health sector in Natuna Regency, it will improve the citizens welfare especially for the dimensions of public health needs. The results of this study describes the improvement of HR aspects can also be interpreted as appropriate HR planning carried out is characterized by quality and quality towards excellent health services contextually.

The results of the interview with the coordinator of the local government official especially where dealing with health matters in Natuna Regency explained that for the performance of all personnel in each work unit in the work environment the Natuna District Health Office could still be improved so as to provide optimal benefits for the health service process implemented. In connection with the organizational structure carried out at this time, concrete steps need to be implemented, especially in the aspect of improvement. The existing human resources include improving the skills and competencies of human resources and developing a good behavior or mindset for improving services in the future.

One of the main problems with regard to develop the organizational structure of the Natuna District Health Office should be to carry out several things related to improving aspects of Human Resources in the work environment of the Natuna District Health Office as follows; In the development of health resources, the Natuna District Health Office currently supervises the health insurance section, the pharmaceutical section, the health facilities and infrastructure and the Workforce Section. In its development it 
turns out that this section has not yet become central in any effort to increase the capacity and competencies as aspired. The implementation of training and development is still not well coordinated, because every other field outside the Field of Health Resources Development also conducts training. Therefore a comprehensive restructuring is needed, such as functionalizing the HR Development Division, so that it is truly a reliable and compatible organizational sub-system for the development of all human resources in the Natuna District Health Office.

Facilities and infrastructure are important factors to support the realization of health development in Natuna Regency, especially in particular the availability of facilities and infrastructure to support health services themselves. Based on the results of the research, it is produced that the condition of facilities and infrastructure in absolute terms is getting better. The availability of existing facilities and infrastructure will certainly improve health services implemented to meet the needs of the community for health in Natuna Regency. In the context of the results of this study, the improvement of aspects of decentralization of health services can also be interpreted properly as the availability of health facilities and infrastructure in Natuna Regency is getting better. The results of the interview with the coordinator of the Regional Working Unit and representatives of the Natuna Regency DPRD members explained that constitutionally there were still irregularities in the realization of the number of health facilities and infrastructure such as the number of service units that tended to exceed the provisions resulting in a large budget burden. Facilities and infrastructure are certainly aimed at adequacy and feasibility, so that if in the realization of the existing structure it actually raises over capacity (One or Two work units), these advantages must be immediately followed up through a comprehensive review so that it decides whether there is a combined work unit or unit deletion work while still looking at the conditions and potential for future organizational conflicts.

Financial support in the form of health budgets from existing APBD posts is also one of the strategic aspects that are important for health planning efforts in Natuna Regency. Based on the results of the study explained that the greater the portion of financial support through the increasing portion of the APBD of Natuna Regency in the field of health, it will improve the welfare of society in general. In the context of the results of this study, this aspect can also mean that there is a strong desire from all parties in Natuna Regency in an effort to improve the quality and quality of health.

The Natuna Regency constantly strives to increase the APBD portion for the development of the health sector, which of course is also supported by the commitment of the regional head and the community through regional legislators who both want health development in Natuna Regency to run smoothly.

The organizational structure performance on local concern. The organizational structure performance on local government provide health services 
as well as benchmarks in the aspects of management and organization of health providers in Natuna Regency must always increase from time to time. This is what can be very important when a budget that will increase incentives for the achievements of existing agencies also has increased(Imran, Muhammad; Rizvi, Syed Hasan Muhammad; Ali, 2011). Based on the results of the description of the data this research was produced that the performance of the agency would have a positive impact on the public trust in Natuna Regency. This means that the better the performance shown, such as achieving the target as effectively and efficiently as possible, will increase the health of the community in a sustainable manner. In the context of the results of this study, the improvement of orientation aspects and performance of health providers in Natuna Regency is getting better than before.

The results of the interview with the coordinator of the Regional Work Unit and representatives of the Natuna Regency DPRD Members especially those dealing with health affairs in Natuna Regency explained that for the performance in achieving all health development efforts at the research location required a change or revision of the structure. This was disclosed with regard to the existence of overlapping and even structural barriers which resulted in optimal performance difficult to obtain. The real conditions show that within the framework of the productivity of medical services for public health in Natuna Regency, it is quite difficult for the existing official local government. This condition was revealed as the existence of health facilities and infrastructure sections and the health insurance section was actually still under the supervision of the HR Development Division in the Natuna District Health Office.

This data and information reinforces the hope of research information sources so that future changes can be made, for example, by moving the section of health facilities and infrastructure sections and health insurance sections to the Health Services Division so as to provide an effective and efficient structure control range while eliminating structural barriers as previously stated.

\section{CLOSING}

\section{Conclusion}

Regional Autonomy according to Law Number 23 of 2014 is the authority of the autonomous region to regulate and manage the interests of local communities according to their own forecasts based on the aspirations of the community in accordance with the legislation so that without going through the provincial government. Districts and cities are responsible for providing most public services such as the need for health services.

This study concludes several things, namely; based on the results of the primary data analysis and discussion of this research can be explained that the policy of regional autonomy in Natuna Regency shows the results of the implementation of authority in the health sector which is reflected in the implementation of the dynamics of the organizational structure of the Natuna District Official Health which is good enough. This shows that as an area that 
still wants to achieve strategic health development, Natuna Regency always allocates good financial resources.

\section{Recomendation}

Besides that, organizational and management factors still require continuous improvement efforts. Therefore, this should increase the implementation of the organization and management within the Natuna Regional Government can be carried out through the efficiency and effectiveness of the performance achievements that have been previously reached.

\section{REFERENCES}

Baartman, L. K. J., \& De Bruijn, E. (2011). Integrating knowledge, skills and attitudes: Conceptualising learning processes towards vocational competence. Educational Research Review, 6(2), 125-134. https://doi.org/10.1016/j.edurev.2011. 03.001.

Bruk, B. V. (2012). Formation of New Ideologies of Administration in American and Russian Administrative Reform. Animal Genetics. Blacksburg, Virginia.

Dinas Kesehatan Kabupaten Natuna. (2016). Rencana Strategis Dinas Kesehatan Kabupaten Natuna Tahun 2016-2021, Ranai: BAPPEDA.

Imran, Muhammad; Rizvi, Syed Hasan Muhammad; Ali, B. (2011). Impact of Organizational Learning on Organizational Performance.: ebscohost. International Journal of Academic Research., Volume 3(4), p424-427. Retrieved from http://web.b.ebscohost.com/ehost/pdf viewer/pdfviewer?vid=10\&sid=43f7f 8d2-b68d-4cf8-be21-

8a70c198757b\%40sessionmgr112\&hi $\mathrm{d}=128 \mathrm{~J}$.

Supranto. (2000). Metode Penelitian. Jogjakarta: Penerbit Rajawali Press.

Mardiasmo. (2006). Aspek Dukungan Keuangan Daerah dan pelaksanaan Otonomi. Jogjakarta: Penerbit Andi.

Mudrajad Kuncoro.(2004).Otonomi Dan Pembangunan Daerah. Jakarta:Penerbit Bumi Aksara.

Rina Herawati \& Deny Junanto. (2007). Pemberdayaan Masyarakat Daerah: Tantangan Dalam Mengelola Sumber Daya Manusia Di Era Otonomi Daerah (Kasus Pembangunan Masyarakat Pertanian di Beberapa Negara. Jurnal Good Governance Vol. 2 Maret 2003. Jakarta: STIA LAN.

Robinson, A. M. (2015). From Old Public Administration to the New Public Service Implications for Public Sector Reform in Developing Countries. UNDP Global Centre for

Public Service Excellence, 1(Public sector reform), 5-7.

Toyota. (2013). Chapter 7 . Organizational Structure and Change Case in Point: Toyota Struggles With Organizational Structure. In Toyota.

Undang-undang Nomor 23 Tahun 2014 tentang Pemerintahan Daerah. (2014). Jakarta: Permata Press. 